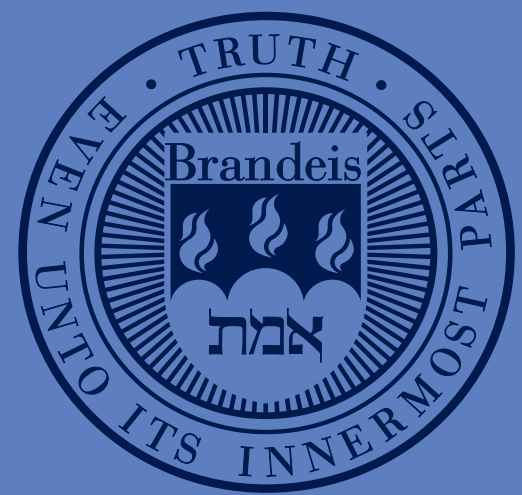

Market Microstructure and the Profitability of Currency Trading

Carol Osler, Brandeis International Business School 


\title{
Market Microstructure and the Profitability of Currency Trading
}

\author{
Carol Osler*
}

\begin{abstract}
Currency trading is a vast and highly profitable business. This paper examines the profitability of two popular currency trading strategies in light of currency-market microstructure research. The carry-trade strategy involves borrowing a low-interest currency and investing the proceeds in a high-interest currency. Technical trading strategies are determined exclusively on the basis of past asset prices and trading volumes. Under the efficient markets hypothesis, neither of these approaches to speculative trading should produce excess returns. The review shows that the profitability of carry-trade investing and technical trading strategies can represent rational longrun equilibria given the structure of currency markets and the incentives and constraints faced by traders.
\end{abstract}

Keywords: Carry trade, technical analysis, skewness, liquidity

JEL Code: F31

* International Business School, Brandies University, Waltham, Massachusetts 02453; email: cosler@brandeis.edu. This review is forthcoming, Annual Review of Financial Economics, Volume 4 (2012). 


\section{INTRODUCTION}

Outright currency speculation has exploded in popularity in recent years, though it was fairly uncommon among asset management firms as recently as 1990 . Bloomberg now lists over 650 currency funds and currencies are now considered a separate asset class. This paper uses findings from currency-market microstructure research to shed light on the profitability of two popular approaches to currency speculation, carry trades and technical analysis.

This profitability of these strategies has long puzzled economists because it appears to violate the efficient markets hypothesis. A carry trade involves borrowing a low-interest currency, investing the proceeds in a high-interest currency, and leaving the resultant currency exposure unhedged. The familiar hypothesis of uncovered interest parity (UIP) implies that the high-interest currency should depreciate on average, largely offsetting the investor's positive net interest income; any remaining profits should just compensate investors for risk. Though this hypothesis serves as a core feature of standard exchange-rate models (Obstfeld \& Rogoff 2003), it is unsupported by the evidence. To the contrary, there is overwhelming evidence that highinterest currencies generally appreciate relative to low-interest currencies (see Hodrick (1987) and Engel (1996) for surveys), and carry-trade investors thereby gain from the currency appreciation as well as the interest differential. Documented returns to carry trades are substantial even after adjustments for transaction costs and standard measures of risk (Burnside, Eichenbaum \& Rebelo 2006).

Technical trading strategies are also profitable in currency markets (Menkhoff \& Taylor 2006). This is perplexing because technical strategists rely exclusively on past asset prices and trading volumes, which are public information. In an efficient market, public information should 
be reflected immediately and fully in asset prices and strategies based on such information should not produce excess returns.

Until the past few years, most attempts to explain the profitability of currency trading strategies relied on exchange-rate models derived from macroeconomic principles that incorporate standard features of efficient markets (Obstfeld \& Rogoff 2003). Though these models have been modified to fit the facts in myriad ways, none of these alternatives has gained wide acceptance. The credibility of macro-based models has also been challenged by evidence that their forecast accuracy is no better than that of the random walk hypothesis (Meese \& Rogoff 1983, Faust, Rogers \& Wright 2003).

The process of exchange-rate determination embedded in macro-based models is essentially unrelated to the process through which currencies are actually traded (Goodhart 1988). With this in mind, a few economists began to analyze the currency trading process more closely (Frankel, Galli \& Giovanini 1996). The existing literature on market microstructure, though primarily focused on equity markets (see Madhavan (2000), Biais, Glosten \& Spatt (2005) for surveys), provided a strong theoretical and empirical foundation for this new line of inquiry. By now, currency-market microstructure comprises a substantial body of research on the basis of which economists are devising new interpretations of exchange-rate dynamics. Some of the findings of this research have helped catalyze rapid progress in demystifying the profitability of currency trading strategies.

This paper reviews the contributions of currency-market microstructure to our emerging understanding of the profitability of currency trading. Section 2 outlines the structure of currency markets. Section 3 reviews key findings of the currency microstructure literature. Section 4 shows how these findings are crucial features of an emerging explanation for carry-trade 
profitability that fits the evidence. Section 4 also highlights inconsistencies between the microstructure evidence and a few alternative theories of carry-trade profitability. Section 5 shows how microstructure analysis sheds light on the profitability of technical trading. Section 6 concludes.

\section{THE STRUCTURE OF CURRENCY MARKETS}

Currencies were possibly the first liquid financial asset traded anywhere. Money changers who stood ready to provide merchants with currencies from different nations are even mentioned in the Bible. As with those ancestors, currency dealers today buy and sell currencies for customers, holding inventory between trades. A gap or “bid-ask spread” between the market makers' low buying (bid) and high selling (ask) prices compensates them for operating costs and risk. This “over-the-counter" (OTC) market structure, modeled formally in Grossman \& Miller (1988), can be observed readily at airport exchange kiosks, where physical currencies quite literally move across counters. However, the vast majority of OTC currency trading now takes place in electronic wholesale markets where deal sizes are measured in millions rather than hundreds and market makers work for major banks.

In today's currency markets, customers are divided into two broad categories: corporates, firms that trade goods and services internationally, and financial customers, primarily asset managers, smaller banks, and central banks. Asset managers, in turn, are informally divided into unleveraged institutional asset managers such as pension funds, mutual funds, and insurance firms, and leveraged money, i.e., hedge funds and their close cousins, commodity-trading associations.

Today's dealers need not hold inventory until new customers arrive but can instead offload inventory quickly and at low cost in an active interdealer market. The share of interdealer 
trading, most recently estimated at 39\% (B.I.S. 2010), is comparable to the share on the London Stock Exchange (Reiss \& Werner 1995) and other liquid OTC markets with interdealer trading. Major dealers use the interdealer market for speculation as well as inventory management (Bjønnes \& Rime 2005). The interdealer market has become the core of the overall foreignexchange market in the sense that quotes to nondealers are set as a spread on the current interdealer quotes.

Although some interdealer trading takes place via the regular OTC market, most now takes place over electronic limit-order markets. Unlike OTC markets, where liquidity providers are clearly defined, in limit-order markets no one is formally assigned to provide liquidity. Instead, every participant chooses between supplying or demanding liquidity on a trade-by-trade basis. Liquidity suppliers post limit orders, which state that the amount they are willing to trade, in which direction they wish to trade (buy or sell), and the worst price they will accept. Liquidity demanders post market orders, which state the amount they will purchase immediately, recognizing that they will get the best prices available from liquidity suppliers. A broker keeps track of these best available limit-order prices and matches them to arriving market orders.

Until the widespread adoption of floating exchange rates around 1973, currency trading was a fairly sleepy profession. Since then, trading has mushroomed and growth remains robust. Between April 1989 and April 2010, daily foreign-exchange trading volume rose from \$620 billion to $\$ 4,000$ billion (BIS 2010). The current figure is 73 times the combined annual exports and imports for the world's 35 largest economies, and 33 times their combined GDP (King, Osler \& Rime 2012). Growth in currency trading was spurred by growth in international trade and cross-border investment, by the advent of electronic trading, and by the entry of retail and high-frequency traders. 
Institutional change has proceeded as rapidly as trading growth. The foreign-exchange market's two-tier structure of the 1970s and 1980s (OTC trading between dealers and customers; order-driven trading between dealers) still dominates, but there are new settings for trading, new groups of traders, and even a new motivation for trading. In the 1970s and 1980s, trading floors were noisy places where dealers shouted to each other while holding multiple telephones to their ears. The market was opaque for all participants. Dealers had to call each other to learn what other dealers were quoting, which helps explain why the share of interdealer trading once exceeded $70 \%$. Customers could not follow market prices in real time and had to call a second or even a third dealer in sequence if their first dealer's quote was unattractive. Today, with the market dominated by electronic trading, telephones are used rarely in the liquid markets, trading floors are fairly calm, and electronic systems post fresh quotes at millisecond frequencies. Additionally, customers have access to streaming intraday quotes and can receive simultaneous quotes from multiple dealers on electronic request-for-quote systems.

By enhancing market transparency, electronic trading raises the bargaining power of customers even as it reduces the costs of trading and trade processing, so bid-ask spreads have naturally tumbled (King, Osler \& Rime 2012). Electronic trading has also spawned an entirely new type of platform, the retail aggregator, which in turn has introduced a new breed of currency trader — the small individual investor. Retail trading is difficult to measure but preliminary estimates suggest it has grown from negligible levels in 2001 to reach $10 \%$ of trading (King, Osler \& Rime 2012).

Electronic currency-trading platforms enable automated strategies. Some of these algorithmic trading strategies are designed to minimize execution costs on large trades by breaking them into smaller transactions distributed across time. Other automated trading 
strategies, known collectively as high-frequency trading, operate at frequencies measured in milli- or even microseconds. High-frequency currency trading initially exploited opportunities for riskless arbitrage across multiple exchange rates or between spot and forward markets. As in other markets, these strategies now also exploit differences in trade-processing delays across trading platforms.

On some of the new electronic limit-order markets, customers can trade directly with each other, effectively competing with the dealers in the provision of liquidity. This competition, which mainly comes from high-frequency traders (Chaboud et al. 2009), has discouraged banks from providing liquidity on such platforms. The banks have instead intensified their focus on providing liquidity to customers in the OTC context, which now operates primarily via proprietary (single-bank) electronic systems. Because these systems require heavy investments in hardware and software, the industry of foreign-exchange dealing has become progressively more concentrated. The number of banks accounting for $75 \%$ of the market, which hovered around 10 in the 1990s, had fallen to 4 by 2010 (King, Osler \& Rime 2012). The concentration of customer business at big dealing banks has enabled those banks to begin warehousing the risk associated with each trade: Rather than lay it off quickly in the interbank market, the largest banks have reverted to their money-changer origins, holding positions until the next customer trade arrives.

This completes our brief tour of the institutional structure of the foreign-exchange market. The next section considers the market's microeconomic structure.

\section{CURRENCY-MARKET MICROSTRUCTURE: SELECT FINDINGS}

Currency-market microstructure research has by now produced a large body of empirical evidence and innovative theoretical frameworks. This section reviews the findings that have proved most valuable for understanding the profitability of currency trading strategies. 


\subsection{Order Flow and Exchange Rates}

The single most important finding in currency-market microstructure is that currency trading flows drive exchange rates. This represented a dramatic departure from earlier perspectives, given that traditional exchange-rate models include neither currency markets nor currency trading. To substantiate the influence of trading flows on exchange rates it was necessary to obtain transaction data, which were unavailable until the late 1990s. Even then the data presented a significant challenge: distinguishing supply from demand when each side of a transaction is a currency. In breakthrough work, Evans \& Lyons (2002) focused on a trade's passive and aggressive parties or, equivalently, the parties supplying and demanding liquidity. Their measure of trading flows, now standard in microstructure, was the difference between the number of aggressive-buy and aggressive-sell trades. They label this "order flow."

The interpretation of order flow is straightforward for customers. If order flow for a group of customers is positive then for those customers, as a group, are increasing their holdings of the currency. This is clear because customers are almost always the aggressor given the currency market's OTC structure. The interpretation of order flow is trickier for interdealer trades. If one dealer buys currency as an aggressor while the other sells it as the passive party, interdealer order flow is non-zero but dealers, as a group, do not change their holdings of the currency. Interdealer order flow is most accurately interpreted as a measure of net liquidity demand.

Evans and Lyons (2002) examine the relation between order flow and exchange rates in a simple linear regression of the exchange-rate's daily change, $s_{t+1}-s_{t}$ (where $s_{t}$ represents the log cost of foreign currency in terms of local currency) on daily interdealer order flow, $\Delta x_{t}$, a fundamental variable, $F_{t}$, and a random disturbance, $\eta_{t}$. 


$$
s_{t+1}-s_{t}=\alpha+\beta \Delta x_{t}+\gamma F_{t}+\eta_{t} .
$$

Their transactions data comprise a major subset of interdealer trading in the dollar-deutsche mark and dollar-yen currency pairs over four months in 1996. Because few macro variables are available at the daily frequency, $F_{t}$ is the difference between domestic and foreign short-term interest rates, $i_{t}-i_{t}^{*}$.

The results of this analysis strongly support the hypothesis that trading flows within the currency market drive currency returns. Interdealer order flow explains up to $63 \%$ of contemporaneous daily returns, whereas the interest differential and lagged returns explain only a few percent. Subsequent studies using different data sets consistently support this finding (Hau, Killeen \& Moore 2002; Berger et al. 2008; Cao, Evans \& Lyons 2006; Rime, Sarno \& Sojli 2010). The empirical estimates suggest that an extra $\$ 1$ in daily net aggressive interbank purchases of a major currency (euro, yen, or UK pound) against the US dollar is associated with an appreciation of that currency on the order of $0.5 \%$. Order flow is likewise a powerful proximate determinant of returns in equity markets (Chordia, Roll \& Subrahmanyam 2002) and bond markets (Brandt \& Kavajecz 2004). ${ }^{1}$

Studies consistently find that the effect of order flow on exchange rates is at least partially permanent (Evans \& Lyons 2002; Payne 2003; Bjønnes \& Rime 2005; Bjønnes, Rime \& Solheim 2005; Killeen, Lyons \& Moore 2006). The possibility that causality goes primarily from returns to order flow, instead of from order flow to returns, has been carefully examined and proves to be unfounded (Evans \& Lyons 2005, Danielsson \& Love 2006). The importance of order flow for returns is underscored by evidence that order flow accounts for up to two-thirds of the influence of news (Love \& Payne 2003, Evans \& Lyons 2008, Rime, Sarno \& Sojli 2010). 
To explain the influence of order flow on exchange rates, economists focus on three dimensions of currency markets that deviate from the perfectly efficient markets of standard exchange-rate models: trading frictions, limits to arbitrage or finite elasticity of demand, and asymmetric information.

3.1.1. Trading frictions. Currency trading is not cost-free-computers must be on, dealers must be paid, capital must provide a return — so currency dealers charge a bid-ask spread. In the presence of such spreads, aggressive purchases (sales) automatically move the price upward to the ask (downward to the bid) on average. In addition, interdealer order flow, as the net of aggressive dealer purchases and sales, automatically has a positive correlation with contemporaneous returns, consistent with the findings of Evans and Lyons (2002).

In the absence of any change in the fundamental exchange rate, however, a price rise to the ask will eventually be reversed by a price decline to the bid. Thus the presence of bid-ask spreads helps explain the existence of a positive relation between interdealer order flow and returns but it does not explain why the relation appears to be permanent.

3.1.2. Limits to arbitrage. If investors are risk neutral and can trade unlimited amounts of an asset, its price will only move in response to the arrival of new information. But currency trading is never unlimited. Dealers are constrained by position and loss limits (Osler 2009); asset managers and retail traders are constrained by funding constraints and risk aversion (Brunnermeier \& Pederson 2008). Rigorous evidence that other asset prices move in response to non-informative shocks comes from Shleifer (1986) for equities and Simon (1991, 1994) for bonds. Lyons and Evans (Lyons 1997, Evans \& Lyons 2002) develop a formal model of currency trading under finite elasticity of demand that now serves as the intellectual workhorse of the field. 
The model postulates a sequence of trading days indexed by $t$, each of which comprises three rounds of simultaneous trading. $N$ identical dealers begin each day with zero inventory of the foreign (base) currency. In Round 1, each dealer is contacted by a customer and quotes a price, $\boldsymbol{P}_{t}^{\mathbf{1}}$, based on available fundamental information. Each customer $i$ trades a random amount, $\boldsymbol{C}_{\boldsymbol{i t}}^{\mathbf{1}}$, and each dealer takes that amount into inventory. In Round 2, each dealer contacts another dealer to trade and they effectively redistribute their aggregate net inventory position, $\sum_{\boldsymbol{i}} \boldsymbol{C}_{\boldsymbol{i}}^{\mathbf{1}}$, evenly among themselves. In Round 3, dealers trade with investors whose constant absolute risk aversion imparts finite elasticity of demand: $\boldsymbol{C}_{\boldsymbol{t}}^{\mathbf{3}}=\gamma\left(\boldsymbol{E}_{\mathbf{2}}\left\{\boldsymbol{P}_{\boldsymbol{t + 1}}^{\mathbf{1}}\right\}-\boldsymbol{P}_{\boldsymbol{t}}^{\mathbf{3}}\right)$. The coefficient $\gamma$, which summarizes the public's risk-bearing capacity, is the inverse of the product of risk aversion and volatility; $\boldsymbol{E}_{2}$ refers to rational expectations formed on the basis of information available in Round 2. Because dealers close each day with zero inventory, $\boldsymbol{P}_{\boldsymbol{t}}^{3}$ must generate sufficient net demand from the Round-3 customers to absorb the aggregate net inventory position the dealers took on in Round 1. If the Round-1 customers are net sellers then the Round-3 customers must be net buyers. Because the Round-3 customers are modeled as risk-averse investors, they will only be net buyers if the anticipated risk premium rises, which requires the foreign currency to lose value over the day, $\boldsymbol{P}_{\boldsymbol{t}}^{\mathbf{3}}<\boldsymbol{P}_{\boldsymbol{t}}^{\mathbf{1}}$. At the higher risk premium the Round-3 investors are willing to hold their new, larger positions indefinitely, so the interdealer order flow of Round 2 is associated with a lasting exchange-rate change.

A given day's price move in this model actually takes place in Round 2, not Round 3. The model postulates that the dealers' aggregate inventory imbalance is publicly revealed in Round 2, so dealers rationally anticipate the extent to which the market price will react in Round 3 when they liquidate their aggregate inventory imbalance. Continuing the previous example, in which Round-1 customers are net sellers, dealers know that the currency's value must fall to 
induce the Round-3 customers to be net buyers, so they set $\boldsymbol{P}_{\boldsymbol{t}}^{\mathbf{2}}<\boldsymbol{P}_{\boldsymbol{t}}^{\mathbf{1}}$. The model assumes that dealers are risk neutral, so in equilibrium $\boldsymbol{P}_{\boldsymbol{t}}^{2}=\boldsymbol{E}_{\mathbf{2}}\left\{\boldsymbol{P}_{\boldsymbol{t}}^{3}\right\}$.

The model of Evans \& Lyons (2002) shows that exchange-rate adjustment is analogous to price adjustment in traditional microeconomic analysis: Daily price moves are driven by the net demand shock from one set of customers and the supply elasticity of another. In referring to this underlying structure, Cao, Evans \& Lyons (2006) distinguish between liquidity-demanding and liquidity-supplying customers. Sager \& Taylor (2006) evocatively describe Round-2 customers as "pushing" the price while the Round-3 customers are "pulled" in to trade by the new price. Bjønnes, Rime \& Solheim (2005) refer to Round-1 and Round-3 customers as demanders and suppliers of overnight liquidity.

In theory, all three of the market's major customer types-financial firms, corporates, and retail traders - could serve as both Round-1 (push) customers or Round-3 (pull) customers. Exogenous influences on financial currency trading include private information about future returns (cash flows), changed perceptions of risk (discount rates), or pure liquidity needs such as end-of-month inflows to retirement funds. Exogenous influences on corporate currency trading include domestic and foreign GDP, inflation, and barriers to trade. Exogenous influences on retail traders include private information (or perceived information, as discussed below) and pure liquidity needs.

Currency demand responds endogenously for financial and retail agents under risk aversion, as noted above. Currency demand responds endogenously for corporate agents given the well-documented influence of exchange rates on relative prices. To illustrate, when the local currency loses value, foreign demand for local products, and thus foreign demand for local currency, will rise. The elasticity of corporate currency demand with respect to the exchange rate 
is typically estimated at frequencies of a month or a quarter, but corporate demand can also respond instantaneously because many firms rely on take-profit orders to ensure prompt trading when prices move in their favor. Take-profit orders instruct a dealer to trade currency on the corporation's behalf once the currency's value reaches a pre-specified level. Each dealer maintains a book of such orders, and in aggregate, they form an instantaneous currency demand curve with finite elasticity (Osler 2005).

The available evidence indicates that, on average, wholesale financial agents tend to be exogenous demanders of overnight liquidity like the Round-1 (push) customers of Evans \& Lyons (2002), whereas corporate and retail agents tend to be endogenous suppliers as with the Round-3 (pull) customers of Evans \& Lyons (2002). As an identification device, researchers note that order flow should be positively (negatively) related to contemporaneous returns for push (pull) customers. A major stylized fact in the literature is that financial order flow is positively related to returns, whereas corporate and retail order flows are negatively related to returns (Lyons 2001; Bjønnes, Rime \& Solheim 2005; Marsh \& O’Rourke 2005; Evans \& Lyons 2007; Amen 2010; Nolte \& Nolte 2012). The timing of trades relative to returns provides additional identification devices. Bjønnes, Rime \& Solheim (2005) find that corporate trades lag financial trades at the half-day horizon, whereas the reverse is not true. Marsh and O'Rourcke (2005) show that corporate order flow, but not financial order flow, responds to lagged daily returns. Nolte \& Nolte (2012) find that retail trades also respond to lagged intraday returns. All these observations are consistent with the hypothesis that financial (corporate) customers are most often serve as push (pull) agents.

3.1.3. Asymmetric Information. Order flow could also influence exchange rates if agents are asymmetrically informed (Bagehot 1971). Glosten \& Milgrom (1985) and Kyle (1985) present 
models describing the process through which private information about an asset's true value influences an asset's price. In both models, uninformed agents infer the asset's true value from the trades of informed agents and the price converges to its true value over time.

In equity markets, private information is gathered daily by armies of analysts who pore over financial reports, meet management, and visit competitors. The nature of private information in currency markets is less obvious, however, because currencies are largely driven by macroeconomic variables, such as prices, interest rates, and output, that are publicly announced. A role for private information emerges when we note that macroeconomic data are necessarily reported with a lag, so motivated traders might combine publicly available data about past macroeconomic conditions with their own insights to derive private estimates of current values (Osler 2009, Evans 2010). Market participants report that leveraged investors are especially active in this endeavor.

Lyons (2001) suggests, alternatively, that private fundamental information is naturally dispersed among customers and that dealers can infer that information by observing patterns in order flow. Strong domestic output, for example, automatically generates rising currency demand from manufacturing firms. A dealer could infer the economy's underlying strength by observing that currency demand is consistently rising among importing firms (also see Evans \& Lyons 2007, Evans 2010). Because trades between dealers and customers are not revealed publicly, that dealer's information would be private.

Whether customers aggressively seek information or passively reveal information through trading motivated by other factors, this perspective implies that customer order flow has predictive power for macro fundamentals and for exchange rates. Evans \& Lyons (2007) provide evidence that daily customer order flow has predictive power for macro fundamentals including 
GDP and inflation at horizons up to two quarters. Evans and Lyons (Evans \& Lyons 2005, Evans 2010) provide evidence that daily customer order flow has predictive power for exchange-rate returns.

Recent currency-market research focuses on the extent to which different agents are privately informed. Many of these Studies focus on the relation between individual trades and subsequent returns, given that rational informed agents should buy (sell) before the price rises (falls). The evidence indicates consistently that financial customers are better informed than corporate customers (Carpenter \& Wang 2003; Osler, Mende, \& Menkhoff 2011). Financial order flow has predictive power for upcoming returns. Corporate order flow, by contrast, has no predictive power for upcoming returns (Bjønnes, Osler \& Rime 2011, Osler \& Vandrovych 2007). This is not entirely surprising, given that most corporate agents do not consult exchangerate forecasts when deciding on currency trades (Bodnar, Hayt \& Marston 1998, Goodhart 1988), a choice that is probably rational given the high cost of controlling risk at firms that permit speculative trading (Osler 2009). Retail currency traders also appear to be uninformed. They consistently lose money (Heimer \& Simon 2011) and their individual transactions are negatively related to future returns (Nolte $\&$ Nolte 2011). The implication that retail traders are not just uninformed but also imperfectly rational is also supported by extensive evidence for imperfect rationality among retail equity traders (e.g., Barber \& Odean 2000).

The possibility that dealers aggregate information gleaned from customer trades has several testable implications. First, large dealers, who have more customers to learn from, should be better informed than small dealers. Extensive evidence now supports this inference (Bjønnes, Osler \& Rime 2011, Moore \& Payne 2011, Phylaktis \& Chen 2010). Because financial customers are generally better informed than corporate customers, another testable implication of 
current theory is that a dealer's information should be positively related to the extent of its financial-customer base and unrelated to the extent of its corporate-customer base. Bjønnes, Osler \& Rime (2011) present evidence consistent with this hypothesis. Bjønnes, Osler \& Rime (2011) and Moore \& Payne (2011) also provide evidence that dealers originate substantial private information of their own, an observation that is not anticipated in the theoretical literature.

\subsection{Bid-Ask Spreads and Price Discovery}

To understand why currency trading strategies are profitable, it has proved valuable to understand the determinants of bid-ask spreads and the process through which information comes to influence the exchange rate. The microstructure evidence in this topic reveals some striking differences between currency markets and other financial markets.

In the equity-inspired model of Glosten \& Milgrom (1985), uninformed dealers trade exclusively with customers. Some customers are informed but the dealer does not know which. Because informed customers exploit any gap between the dealer's quoted price and the asset's true value, dealers will lose to such customers on average. Rational dealers quote prices that are "regret-free" in the sense that they incorporate the expected information content of any given trade. Studies consistently show that NYSE bid-ask spreads incorporate an adverse-selection component as predicted by this model (Glosten \& Harris 1988, Madhavan \& Smidt 1993, Huang \& Stoll 1997).

Osler, Simon \& Sherman (2012) provide evidence that bid-ask spreads in the interdealer tier of the foreign-exchange market also incorporate a substantial adverse-selection component. This seems logical given the evidence for information asymmetries among dealers cited earlier. The picture is different, however, in the customer tier of the foreign-exchange market. Cross- 
sectional variation in the bid-ask spreads quoted to customers follows a pattern that is inconsistent with the predictions of adverse-selection models. These models imply that spreads should be wider on trades most likely to be informed, and more specifically that spreads should be wider for larger trades (Easley \& O’ Hara 1987, Glosten 1989), and wider for financial customers than corporate customers. Careful tests based on dealer transaction data show, however, that bid-ask spreads are narrower for larger customer trades (Ding 2008; Osler, Mende \& Menkhoff 2011) and narrower for financial trades than for corporate trades (Reitz, Shmidt \& Taylor 2009, Osler, Mende \& Menkhoff 2011). This evidence indicates that adverse selection is not a major influence on the bid-ask spreads quoted to customers in foreign-exchange markets.

The inverse relation between customer bid-ask spreads and trade size could reflect the fixed component of dealers' operating costs, given that a fixed cost can be covered with a smaller proportionate spread on a larger trade. Fixed operating costs cannot explain, however, why better informed financial customers pay narrower spreads. Osler, Mende \& Menkhoff (2011) discuss a number of mutually consistent explanations for the variation between financialand corporate-customer bid-ask spreads. Most critically, the variation in bid-ask spreads could be influenced by asymmetric information about market structure and current market conditions. The currency market's two-tier structure gives informed customers some real-time market power when negotiating prices with their dealers (Green, Hollifield \& Schurhoff 2007). They can exploit the fact that dealers have an incentive to learn whether they are buying or selling, given that this information gives the dealers a strategic advantage in subsequent interdealer trading (Naik, Neuberger \& Viswanathan 1999). Corporate traders, on the other hand, face few incentives to develop much familiarity with the market, and their lack of understanding provides the dealers with market power. Evidence presented by Reitz, Shmidt \& Taylor (2009) supports 
the hypothesis that financial customers have greater market power relative to their dealers than corporate customers.

Given the inverse relation between bid-ask spreads and the information content of customer trades, price discovery in currency markets is unlikely to occur in the customer market and thus unlikely to follow the process outlined in Glosten \& Milgrom (1985). Osler, Mende \& Menkhoff (2011) propose an alternative price discovery process consistent with the currency market's two-tier structure in which a customer's information moves through the market in three stages. In Stage 1, the dealer observes a customer's trade direction and thereby infers whether the customer believes the market is over- or under-valued. Because customer prices are influenced by strategic considerations rather than adverse selection, that information is not yet embedded in the customer's quoted price. In Stage 2, the dealer uses the information just gathered to inform his interdealer trades. At this stage the information does become embedded in the interdealer price. In Stage 3, customer prices automatically move in response to the new interdealer price.

A critical feature of Stage 2 is a tendency of dealers to trade more aggressively after informed than after uninformed customer trades. The idea that informed agents are likely to trade aggressively is predicted in theoretical treatments of limit-order markets (Harris 1998, Foucault 1999). After trading with an informed customer and learning that customer's information, a currency dealer has two additional incentives to trade aggressively: The dealer has taken on the customer's inventory and associated inventory risk, and the dealer's information indicates that this inventory position is likely to incur a loss. Evidence that dealers are indeed more likely to make aggressive trades after informed customer trades is presented by Osler, Mende \& Menkhoff (2011) and Bjønnes, Osler \& Rime (2011). 
The tendency of dealers to trade aggressively in parallel with their informed customer trades implies that interdealer order flow should carry information about exchange-rate fundamentals. Rime, Sarno \& Sojli (2010) support this hypothesis with evidence that interdealer order flow carries information about upcoming macroeconomic data releases.

\subsection{Price-contingent Trading}

Price-contingent trading strategies are common in currency markets (Osler 2009). Such strategies can have distinctive effects on the behavior of asset prices and the profitability of some popular currency trading strategies may owe much to their use.

Price-contingent trading is often formalized as stop-loss and take-profit orders. Stop-loss orders involve positive-feedback trading since they mandate purchases (sales) after price rises (declines). Take-profit orders involve negative-feedback trading given that they mandate sales (purchases) after price rises (declines). In both cases the dealer must trade a fixed quantity of currency at the best available price once the currency trades at the pre-specified trigger level. Each currency dealing bank monitors a book of stop-loss and take-profit orders for customers and other dealers (Osler 2003); at the biggest banks, this order book is passed from one office to another as trading progresses daily around the globe. Stop-loss buy and sell orders are treated symmetrically in the wholesale currency market, as the sale of one currency is just the purchase of another. ${ }^{2}$ Both stops and take profits are conditional market orders rather than limit orders, so their execution generally raises liquidity demand.

Given the influence of order flow on returns, the negative-feedback trading associated with take-profit orders should tend to dampen trends and stabilize the market. Likewise, the positive-feedback trading associated with stop-loss orders should accentuate trends. Stop-loss orders can even generate price cascades, meaning strong self-reinforcing trends, given that the 
execution of one order can push the market price to new levels that trigger the execution of yet more orders. Market participants report seeing small stop-loss-driven price cascades daily or weekly and describe price dynamics during such events as "gappy," meaning the price skips some levels. Stop-loss orders also influence dynamics in equity markets. Canadian and US investigators cite stop-loss orders as a significant contributor to the flash crash of May 2010 (CFTC-SEC 2010, IIROC 2010). Portfolio insurance, a strategy involving positive-feedback trading, is widely considered to have been a major factor behind the October 1987 stock-market crash (Genotte \& Leland 1990).

Osler \& Savaser (2011) use simulations calibrated to statistically accurate properties of price-contingent orders to examine how these orders influence exchange rates. Their simulations indicate that conditional trading could account for half or more of the fat tails in exchange-rate returns. Three properties of these orders are shown to compound the effect of positive-feedback trading on the frequency of extreme returns: fat tails in the statistical distribution of order sizes, a tendency of order executions to cluster at specific exchange-rate levels, and a tendency of executions to cluster during times of heightened volatility.

This section has reviewed microstructure theory and evidence concerning the influence of order flow on exchange-rate returns, the determination of bid-ask spreads, the price discovery process, and price contingent trading. I next show how these insights help explain the profitability of carry trades and technical analysis.

\section{MICROSTRUCTURE AND THE CARRY TRADE}

The sustained profitability of carry trades may be the single most important reason why currencies have grown explosively an asset class since 1990. These profits are substantial: Brunnermeier, Nagel \& Pedersen (2008), for example, find average quarterly profits of 0.022 to 
a standard carry trade over the period 1986-2006, an annualized excess return of 9\%. For concreteness, Figure 1 depicts information about a carry trade popular for much of the past decade. New Zealand's interest rates exceeded those of Japan by five to seven percentage points from 2000 through 2009, so the Japanese yen was often used as a funding currency for carry trades where the New Zealand dollar was the investment currency. This trade paid off handsomely for most of this period, as net interest income was augmented by a fairly steady rise in the value of the New Zealand dollar.

The profitability of carry trades is closely associated with a large body of econometric research on UIP. This is typically represented as follows: $E_{t}\left\{s_{t+1}\right\}-s_{t}-\left(i_{t}-i_{t} *\right)=r p_{t}$, where $E_{t}\left\{s_{t+1}\right\}-s_{t}-\left(i_{t}-i_{t}^{*}\right)$ is the excess return and $r p_{t}$ is the risk premium. Under rational expectations, forecast errors have mean of zero and are orthogonal to existing information, so it is standard to test this using realized returns:

$$
s_{t+1}-s_{t}=\alpha+\beta\left(i_{t}-i_{t}^{*}\right)+\varepsilon_{t} .
$$

The constant, $\alpha$, is interpreted as a constant risk premium and the regression residual, $\varepsilon_{t}$, is interpreted as the expectation error. Though UIP predicts $\beta=1$, at time horizons of a year or less studies consistently find $\beta<0$ (the evidence is surveyed in Hodrick (1997) and Engel (1996); Breedon, Rime \& Vitale (2012) provide recent confirmation). This implies that high-interest currencies tend to appreciate, allowing currency carry-trade investors to earn both the interest differential (or carry) and the currency return.

The apparent failure of UIP could reflect a time-varying risk premium. Researchers have been unable to connect carry-trade profits to traditional risk measures such as the variance of returns, however, despite a myriad of attempts (Hodrick 1987, Engel 1996). The failure of 
rational expectations is a natural alternative hypothesis that gains plausibility from studies showing that professional exchange-rate forecasts are biased and inefficient (MacDonald (2000) provides a survey). This probably does not represent peso problems: The data in some studies cover extensive periods of time so the realized distributions of exchange-rate returns should closely approximate the true distributions. Evidence that imperfect rationality helps explain carry-trade profitability is provided by Breedon, Rime \& Vitale (2012), a careful study using forecasts from actual currency traders. Nonetheless, the hypothesis of imperfect rationality leaves the bulk of carry-trade profits unexplained.

It is now recognized that risk may be better measured by return skewness than by return variance. Market participants have long been familiar with a tendency for carry-trade returns to "unwind" rapidly in a burst of big losses. Participants describe this pattern as "going up by the stairs and coming down in the elevator" (Breedon 2001; quoted in Plantin \& Shin 2008). The most recent financial crisis included a major carry-trade unwind in August of 2007 and an even bigger unwind in late 2008 (Melvin \& Taylor 2009). Both episodes are readily apparent for the Japanese yen-New Zealand dollar exchange rate depicted in Figure 1. Market participants are constantly alert for signs of market fragility, which they glean from the futures position data of the Commodities Futures and Trading Commission and from a daily FX Positioning Index published by Nomura (Amen 2010), among other sources.

The asymmetric pattern of returns just described implies that returns to the currencies commonly used in carry trades should be highly skewed, with negative skew for investment currencies and positive skew for funding currencies. Brunnermeier, Nagel \& Pedersen (2008) confirm this pattern in the skewness of quarterly returns (all relative to the US dollar) during the period 1986-2006. For two of the most popular investment currencies of recent years, the New 
Zealand dollar and the Australian dollar, they find skewness of -0.297 and -0.322 , respectively. For two of the most popular funding currencies, the yen and the Swiss franc, they find skewness of 0.318 and 0.144 , respectively.

Because investors generally prefer positive skewness (Harvey \& Siddique 2000), the natural inference is that positive mean returns to carry compensate investors for negative skewness in returns. Jurek (2009) provides evidence consistent with this hypothesis. The underlying source of risk could be even deeper. Carry-trade returns have been connected to both bond-market risk factors (Clarida, Davis \& Pedersen 2009) and equity-market risk factors (Brunnermeier, Nagel \& Pedersen 2009, Menkhoff et al. 2011). Nonetheless, it is clear that normal carry-trade returns tend to reverse abruptly under conditions of financial market stress. In a rational equilibrium, the risk associated with these abrupt losses will require some compensation.

\subsection{Microstructure and the Carry Trade}

The stylized facts associated with carry-trade returns can now been explained using insights from several conceptual frameworks that build on insights from currency-market microstructure. One framework helps explain the normal modest gains; others help explain the abrupt losses during financial-market stress.

4.1.1. Microstructure of carry-trade gains. Positive returns to carry emerge as an equilibrium phenomenon in the model of Plantin \& Shin (2008). In brief, these authors hypothesize that carry traders' own purchases of the investment currency create positive order flow which, in turn, generates positive returns to that currency. The returns do not happen instantaneously because capital is slow-moving and because leverage is procyclical. Over time, "[ $\mathrm{t}]$ he belief in the 
success of carry trades can thus become self-fulfilling, and the failure of uncovered interest parity becomes the consequence of carry trades" (Plantin \& Shin 2008, p. 3).

Microstructure research enables us to envision how this plays out step by step, and evidence supports this detailed vision. As hedge funds, proprietary traders, and other leveraged investors open carry-trade positions, their purchases of the high-interest currency generate positive financial order flow (with trades measured in the high-interest currency), because they tend to be liquidity demanders (customers) rather than liquidity suppliers (dealers). The financial-customer order flow is mostly mediated by spot dealers. The interdealer price soon responds given that dealers realize that by the end of the day this net liquidity demand must be offset by liquidity supply provided with finite elasticity by other customers (Evans \& Lyons 2002). In this way, positive net purchases of the high-interest currency by leveraged investors generates positive returns to that currency.

As this process develops, interdealer order flow will tend to be positive, because dealers rationally make aggressive trades in parallel with their informed customers (Osler, Mende \& Menkhoff 2011). This prediction is supported by evidence presented by Breedon, Rime \& Vitale (2012). In their interdealer transactions data covering the period 1997-2007, there is a strong association between interest differentials and interdealer order flow for euro-dollar and dollaryen, two currency pairs widely used in the carry trade. The reasons why carry trades are associated with interdealer order flow merit closer scrutiny, given that interdealer order flow is so easy to misunderstand. Suppose that a financial customer buys currency from a dealer to open a carry trade. The dealer will tend to aggressively purchase the same currency shortly thereafter, motivated in part by the need to eliminate the inventory position taken on when providing liquidity to the customer. The dealer might even trade a bit more so as to open a speculative 
position. Dealers know that leveraged investors tend to adopt a few well-known strategies, so the observation of one leveraged-investor trade suggests similar trades by other leveraged investors elsewhere in the market. Because order flow has a swift influence on returns, the dealer can reasonably anticipate an intraday exchange-rate response. Dealers do not generally hold open carry-trade positions: Returns to carry are earned over weeks or months whereas dealers usually close positions within a minute (Bjønnes \& Rime 2005). Thus, though it may sometimes not be obvious, interdealer order flow will not reflect dealer carry-trade positions (Breedon \& Vitale 2010). ${ }^{3}$

Carry-trade positions do not instantly reach full size because capital is "slow moving," meaning there are nontrivial time delays associated with asset allocation process (Mitchell, Pedersen \& Pulvino 2007). Investors must first choose a strategy, which often involves research and committee meetings, then communicate that strategy to the traders, who then implement the strategy.

As highlighted by Plantin \& Shin (2008), the expansion of carry-trade positions will not be sustained, even with slow-moving capital, unless trading is in some way self-reinforcing. A natural self-reinforcement mechanism is present in leverage. As investing firms earn carry-trade profits, their balance sheets become stronger, rational lenders become more willing to provide credit, and funds can invest even more (Adrian \& Shin 2008, Brunnermeier \& Pedersen 2008). History suggests another process through which carry-trade investing becomes self-reinforcing, a process that involves social learning as outlined by Kaustia \& Knüpfer (2011). Many skeptical investors initially chose not to undertake carry trades, suspecting that the apparent excess returns were chimerical given that the risks involved were poorly understood. Those brave enough to 
take positions realized substantial gains with only moderate risk, however, which encouraged the skeptics to open positions after all.

Two studies confirm empirically that carry positions expand over time. Froot \& Ramadorai (2005) examine net investor currency purchases following a positive shock to a major currency's (real) interest differential vis-á-vis another major currency. Their evidence shows that net purchases intensify over the first few weeks and then continue, though diminishing steadily, for many months. Brunnermeier, Nagel \& Pedersen (2008) show, using VARs, that larger forecasted interest differentials are associated with larger open speculative currency futures positions.

As open carry positions expand, the investment currency continues to appreciate and carry-trade positions continue to profit. This pattern receives support from the VARs of Brunnermeier, Nagel \& Pedersen (2008), which show that carry-trade returns cumulate over time after an interest-differential shock. These VARs also indicate that returns initially underreact relative to the simple UIP benchmark and eventually overreact, consistent with the implication of Plantin and Shin (2008) that carry-trade returns are manifestations of a bubble.

4.1.2. Microstructure of carry-trade losses. The model of Plantin \& Shin (2008) does not focus on the downside of carry-trade returns, but instead simply assumes that an exogenously determined currency crash occurs with fixed probability. To develop an understanding of carry-trade unwinds I synthesize several papers with microstructurally plausible and mutually consistent mechanisms for generating market crashes.

Brunnermeier \& Pedersen (2008) outline a generic crash model that shares many features with bond markets. The model includes market makers who provide liquidity to "customers" but 
who also hold substantial inventory positions. These market makers are subject to procyclical leverage in the form of a margin constraint imposed by their "financiers." A rise in volatility or an adverse wealth shock to market makers can bring about margin calls. Market makers sell assets to meet the margin call, the asset sales reduce the assets' value, and margin calls intensify. The model has two key implications for the carry trade: (a) A market with procyclical leverage can have multiple equilibria and $(b)$ markets can become fragile, in the sense that a small adverse shock can cause a shift from a high-liquidity, high-price equilibrium to a low-liquidity, low-price equilibrium.

Brunnermeier, Nagel \& Pedersen (2008) use the model just described as an interpretive filter in their rich empirical study of carry-trade returns, because the model's general idea seems broadly plausible: Carry trades are typically undertaken by hedge funds, which rely heavily on leverage and are definitely subject to margin calls. Consistent with a potential role for procyclical leverage, Brunnermeier, Nagel \& Pedersen (2008) find that a rising VIX index, which indicates heightened market risk and/or risk aversion, is indeed associated with carry-trade unwinds.

Nonetheless, Brunnermeier \& Pedersen's (2008) model needs to be interpreted loosely in the context of currency markets because some of its key structural features are not consistent with the institutional structure of currency markets. In currency markets, for example, leveraged investors generally demand liquidity whereas the model assumes they supply it. Furthermore, currency dealers generally do not hold positive inventory overnight so they do not become finance-constrained during crises. To the contrary, currency dealers profit handsomely during crises as bid-as spreads widen. These gaps between the model and currency-market reality may explain why Brunnermeier, Nagel \& Pedersen (2008) find no statistical relation between the 
spread between Treasury and eurodollar yields, a proxy for funding illiquidity, and a proxy for speculative trading in the currency futures markets.

Brunnermeier \& Pedersen's (2008) model also has trouble explaining why carry-trade unwinds are typically concentrated on just a few days. During the unwind of October 1998, for example, the dollar-yen exchange rate dropped 12 percentage points over three days (7-9 October; Oanda data), well over half its 17-percentage-point peak-to-trough decline. Likewise, the Australian dollar-Japanese yen exchange rate fell 7.7 percentage points on August 16, 2007, well over half that unwind's 11-percentage-point peak-to-trough decline. Yet the dynamic processes outlined by Brunnermeier \& Pedersen (2008) generally involve logistical delays at each step. Margins are raised after volatility becomes elevated, but to justify such a move the higher volatility must be observed for a few days or weeks; the asset sales associated with higher margins take yet more days or weeks to materialize owing to decision and implementation lags; etc. In short, shifts between market equilibria governed by the mechanism of Brunnermeier \& Pedersen (2008) seem likely to play out over weeks or months rather than days.

The swiftness of currency crashes is readily explained, however, by conditional trading strategies under asymmetric information. Carry-trade returns are maximized if an investor liquidates his positions just as a market reversal gets under way, so investors have a strong incentive to time the market. But the timing of a reversal cannot be predicted with much accuracy because currency information is dispersed. As Abreu \& Brunnermeier (2003) demonstrate, under these circumstances traders will not simultaneously and immediately liquidate positions in anticipation of a crash and bubbles can emerge in equilibrium.

With a wait-and-see approach to timing the market, traders' sales are contingent on the emergence of a downtrend and there therefore necessarily involve positive-feedback trading. But 
the very existence of positive-feedback trading strategies increases market fragility and contributes to crashes when they occur (Genotte \& Leland 1990, Abreu \& Brunnermeier 2003, Osler 2005). As open positions accumulate, more agents plan positive-feedback trading in the event of a market downturn, which further increases the risk of a crash. In effect, not just carrytrade returns but also carry-trade fragility may be self-fulfilling. Because returns can reverse quickly and information is dispersed, investors rationally protect positions with positivefeedback trading strategies. The existence of such strategies, however, creates the very market fragility that motivates their use.

This positive relation between crash risk and the extent of carry trading is supported by evidence presented by Brunnermeier, Nagel \& Petersen (2008). Their VAR analysis indicates that large anticipated interest differentials, which bring rising carry-trade positions over time as reported above, are also associated with more negative future skewness in returns. A positive relation between crash risk and the extent of carry trading is also supported by the strong negative relation between realized skewness and lagged interdealer order flow identified in Breedon, Rime \& Vitale (2012).

Some of the market's intended positive-feedback trading will be formalized as stop-loss orders. In effect, traders who cannot actively monitor the market use these orders to outsource the monitoring function to their dealers. ${ }^{4}$ Placing stop-loss orders further intensifies market fragility, because dealers have no flexibility: They must execute such orders promptly and in full. Reliance on stop-loss orders also increases the likely speed of any crash by eliminating communication delays between dealers and customers. Stop-loss orders can bring market crashes even without any initial news trigger (Osler and Savaser 2011), as has occurred for some carrytrade unwinds (Cai et al. 2001). 
The stop-loss orders executed during a carry-trade unwind necessarily absorb interdealer market liquidity. In the extreme, a price cascade becomes a liquidity black hole (Morris \& Shin 2004). This has two testable implications: (a) currency markets should be less liquid during carry-trade unwinds and $(b)$ the illiquidity should be particularly pronounced for currencies involved in the carry trade. Mancini, Ranaldo \& Wrampelmeyer (2011) provide extensive evidence consistent with both of these implications.

To summarize, carry-trade returns can be understood through the fusion of multiple perspectives that rely on microstructural features of currency markets. The positive returns appear to be a logical consequence of the way order flow influences returns. When that effect is combined with the tendency of capital to be slow-moving and the tendency of leverage to be procyclical, investor participation in the carry trade can generate an exchange-rate bubble. The positive returns to carry trades potentially become fragile for at least two reasons. Margin calls and haircuts can turn a small downturn into a big one, as can the positive-feedback trading strategies that carry traders use to protect their positions.

The profitability of carry trades, from this microstructurally informed perspective, is not chimerical. It does not reflect a peso problem or, more generally, a systematic divergence between the historical distribution of returns and the true distribution. Instead, the profitability of carry trades represents equilibrium compensation for the negative skewness of returns, a form of risk.

4.1.3. Sustainability of the carry trade. Though economists typically expect strategies with excess returns to become less profitable and less popular over time, the popularity of the carry trade has tended to rise, instead. The continued profitability of the carry trade can be interpreted in terms of interactions among strategies. The key decisions associated with carry trades are all strategic 
complements: The more one group adopts those strategies the greater the potential gains to others from adopting the same strategies. As more investors open carry-trade positions, raising the value of the investment currency, other investors face stronger incentives to open carry-trade positions themselves. Similarly, as more investors put in place positive-feedback trading strategies as protection from crash risk, other investors face stronger incentives to rely on positive-feedback strategies.

\subsection{Other Carry-Trade Models and the Microstructure Evidence}

Not all carry-trade models are supported by microstructure evidence. This section highlights reasons to question models focused on adverse selection, rare disasters, and consumption risk.

4.2.1. Adverse selection and the carry trade. Burnside, Eichenbaum \& Rebelo (2009) analyze the carry trade using a modified version of Glosten \& Milgrom's (1985) equity-inspired model. Carry-trade profitability in this model derives from the influence of adverse selection on the bidask spreads paid by customers. Microstructure features differ widely across markets, however, and adverse selection has been shown to have little influence over customer spreads in currency markets (Ding 2008, Osler, Mende \& Menkhoff 2011, Reitz, Schmidt \& Taylor 2009). As discussed in Section 3, these spreads appear to be driven, instead, by strategic considerations associated with the two-tier structure of currency markets.

4.2.2. Rare disasters and the carry trade. Fahri et al. (2009) derive econometric estimates of a currency crash risk premium based on a model in which short-term interest rates are endogenously determined as stochastic discount factors. Short-term interest rate differentials in this model are driven exclusively by international differences in the risk of a massive financial catastrophe. Because short-term interest rates are in reality largely controlled by central bankers, this can only be true if central bankers worry about catastrophe risk. But during most of the 
paper's sample period, January 1996 through June 2008, central bankers were congratulating themselves on taming the business cycle, which left them complacent about catastrophe risk (Bernanke 2004). Even if catastrophe risk had been among the major concerns of central bankers, influential central bankers were philosophically opposed to allowing such risk to influence monetary policy (Bernanke \& Gertler 1999). The model of Fahri et al. (2009) is also notable for excluding the macroeconomic factors that central bankers do actively consider in setting short-term interest rates, most notably inflation and unemployment.

Fahri et al.’s (2009) empirical identification strategy has surprising implications given that it requires that the potential catastrophes that drive interest-rate differentials exceed in magnitude anything observed during their sample period. Consider the interest differentials that arose between developed and Asian countries after the 1997 Asian financial crisis, and the differentials that arose between developed countries and Argentina after Argentina's 2001-2002 financial collapse. Fahri et al.’ (2009) identification strategy implies that these extreme differentials did not reflect the financial calamities that had just happened, but instead reflected the possibility of some future calamity far worse.

4.2.3. Consumption risk and the carry trade. Lustig \& Verdelhan (2007) suggest that carry-trade returns represent compensation for the risks associated with consumption growth. This is an attractive explanation insofar as it focuses on a factor suggested by theory. Unfortunately, however, the microstructure evidence does not support a core assumption of the model: traders are concerned about consumption risk.

Consider, for example, currency dealers at banks. The incentives faced by these traders are structured consistently across institutions, presumably because these institutions have in common the need to align traders' incentives with those of their managers and, ultimately, with 
those of shareholders. A large share of a dealer's compensation comes in the form of a bonus tied to his personal profitability and to the profitability of his trading floor; neither measure is related to consumption risk. A dealer's risk is controlled through position and loss limits; these limits are determined by the firm's value-at-risk and the traders' own profitability, considerations that are likewise unrelated to consumption risk. Individual bank dealers may also respond to a more personal dimension of risk — the risk of losing the profits earned within the current bonus cycle before bonuses are actually awarded-but consumption risk is unrelated to bonus cycles.

We next consider asset management firms. Portfolio managers face incentives similar to those of bank dealers, but they do not usually make the individual trading decisions. These decisions are made by the funds' currency traders, who are typically evaluated on execution quality rather than risk. Corporate traders, such as the firms for which they work, primarily need currencies for transaction purposes so consumption risk is again orthogonal to trading decisions. Even retail traders are unlikely to be motivated by consumption risk, because most retail positions are held for only a few hours (Heimer \& Simon 2011). Retail trading could not explain the evidence for carry-trade profitability in any case, because those profits emerged with floating exchange rates in the 1970s whereas active retail trading only emerged after 2000.

\section{MICROSTRUCTURE AND TECHNICAL ANALYSIS}

Ever since major exchange rates were allowed to float in the 1970s, rigorous studies have identified technical trading strategies that are significantly profitable even after adjustments for transaction costs and risk (for a survey, see Menkhoff \& Taylor 2006). Some of these profitable strategies involve the use of moving averages or momentum rules to identify trends as they emerge; others involve the use of support and resistance levels to anticipate trend reversals. 
The profitability of technical analysis runs counter to the prior beliefs of most academic economists. Malkiel's (1990) view is typical: “Technical strategies are usually amusing, often comforting, but of no real value" (p. 154). With respect to equity markets in developed countries, the evidence generally supports the academic view that technical trading strategies are not profitable (Bessembinder \& Chan 1998, Park \& Irwin 2007, Bender, Osler \& Simon 2012). Undeterred by academic disdain, currency traders rely heavily on technical analysis. The vast majority of dealers sometimes or always rely on technical trading signals (Taylor \& Allen 1992, Menkhoff 2001, Menkhoff \& Gehrig 2006, Lui \& Mole 1998, Cheung \& Chinn 2001), and this reliance shows no sign of decline over time (Cheung \& Chinn 2001). Among retail traders, 89\% rely on technical analysis, and within this group, $40 \%$ rely exclusively on technical analysis (Citi FX Pro 2010).

This section reviews insights from currency microstructure research that help explain the predictive success of technical analysis after discussing the market's reliance on technical analysis.

\subsection{The Microstructure of Trend-Following Technical Strategies}

Foreign-exchange market participants assign trend-following strategies a fairly high degree of reliability in forecasting short-term returns (Lui \& Mole 1998). Rigorous research confirms that these strategies do indeed tend to be profitable for major dollar-based exchange rates (Levich \& Thomas 1993; Chang \& Osler 1999, Dueker \& Neely 2007). The profitability of trend-following strategies can potentially be explained using the microstructurally based analysis of carry-trade returns just discussed. That is, the trends identified by technical trading strategies could theoretically emerge from the self-fulfilling dynamic described for carry trades in Section 4. 
The connection between carry trades and technical trading profits could be quite direct if technical signals have generally been identifying trends generated by carry-trade investing. This possibility, if it were true, could help explain the apparent decline in the profitability of trendfollowing strategies in major dollar-based exchange rates since the mid-1990s (Olson 2004). That decline roughly coincided with a major shift in carry-trade activity from dollar-based exchange rates to various cross rates, including but not limited to cross rates involving the yen. The possibility that technical signals of trends have identified trends generated by carry trades, coupled with the absence of a clear parallel to the carry trade in developed-country equity markets, could also help explain why technical strategies seem to be less profitable in those markets than in currency markets.

The profitability of technical trading might, alternatively, share no more with carry trades than a similar self-fulfilling mechanism. The self-fulfilling bubble process outlined in Plantin \& Shin (2008) does not depend on the existence of an interest differential, and in any case technical analysts focus on directional predictions and risk protection rather than costs of carry. If technically focused traders agree that a trading signal has been observed and begin to take positions, and if self-reinforcing dynamics such as procyclical leverage or peer influence are operative, self-fulfilling trends detectible by technical analysis could emerge independently of the carry trade.

\subsection{The Microstructure of Support and Resistance Levels}

Support and resistance levels are the stuff of daily conversation on trading floors. A support level is an exchange-rate level at which traders believe any downward trend is likely to pause or reverse; a resistance level is defined symmetrically relative to upward trends. Market participants 
believe support and resistance levels have substantial predictive power for trend reversals, and there is a small industry associated with identifying these levels.

Technical analysis predicts not only that trends will reverse at support and resistance levels, but that if one of these levels is crossed the trend will immediately intensify. Osler (2000) provides evidence that both these predictions hold true for daily support and resistance levels provided by six professional analysts to their customers.

Currency-market microstructure sheds light on the underlying market mechanisms behind this predictive power and explains why it may be consistent with optimizing behavior among individual traders. Central to this analysis is the tendency of traders to favor certain trigger rates when placing conditional orders (Osler 2003). For both stop-loss and take-profit orders, traders favor rates ending in zero and five. More critically, the trigger rates for stop-loss and take-profit orders cluster asymmetrically near these round numbers. Take-profit orders are relatively likely to be triggered as the exchange rate approaches a round number, whereas stop-loss orders are relatively likely to be triggered just after the exchange rate crosses a round number.

To appreciate the implications of these asymmetric clustering patterns it is helpful to examine carefully the likely sequence of events as an exchange rate falls toward a round number. Each new, lower exchange-rate level triggers take-profit buy and stop-loss sell orders. Given the way these orders cluster, take-profit buy orders will tend to be triggered more frequently than stop-loss sell orders as the rate falls toward the round number. The execution of these orders will put upward pressure on the price because order flow influences exchange rates. This helps to fulfill the technical analysts' prediction that trends tend to reverse at support levels, given the influence of order flow on returns. When the exchange rate finally reaches the round number, it will trigger roughly equal numbers of take-profit buy and stop-loss sell orders, which largely 
neutralize each other with respect to returns. After the exchange rate crosses below the round number, stop-loss sell orders will tend to be more common. The execution of these orders will put pressure on the rate, helping to fulfill the technical analysts' prediction that trends intensify after rates cross critical levels. Osler (2005) provides empirical evidence that exchange rates tend to reverse course at round-numbered levels and to trend rapidly after crossing such levels, consistent with these predictions.

Take-profit orders and limit orders both involve negative feedback trading, and limit orders in US equity markets tend to cluster at specific levels such as recent extrema (Niederhoffer \& Osborne 1966, Kavajecz \& Odders-White 2004). The parallel extends further, given that trends in US equity prices tend to stall or reverse at levels where limit orders cluster (Niederhoffer \& Osborne 1966, Kavajecz \& Odders-White 2004). Kavajecz \& Odders-White (2004) interpret these reversals in terms of the liquidity provided by limit orders. Suppose a large market sell order pushes the price down to a mass of limit buy orders. Those limit orders might provide sufficient liquidity, relative to the liquidity demand embodied by the market sell order, to prevent any further price decline; in the meantime, market buy orders that move the price back up might arrive. On average, then, clusters of limit orders will be associated with trend reversals, though they will not directly cause the reversals.

This liquidity explanation for trend interruptions can be relevant to currency markets, despite a critical difference between limit orders and take profit orders: Limit orders provide liquidity whereas take-profit orders are conditional market orders that by definition absorb liquidity. The relevance of the liquidity story emerges when we note that dealers hedge customer take-profit orders by placing their own limit orders in the interdealer market. In consequence, the 
interdealer price, when it approaches a round number, could experience the asymmetric balance of liquidity just described for equity markets.

As with the profitability of trend-following technical strategies, the clustering tendencies of conditional currency orders may be rationally self-sustaining. Consider first take-profit orders. Suppose an investment manager needs a currency and decides to place a take-profit buy order near some round number (which will by definition be below the market's current quotes). It could be rational to place the take-profit buy order directly on the round number, because the known clustering of take-profit orders on round numbers suggests a profitable downtrend could stop or even reverse at that level. A trigger rate just above the round number could be even wiser, because take-profit buy orders also cluster just above round numbers so there is always the risk that a downtrend reverses before reaching the round number. A trigger rate below the round number would not be rational because the known clustering of stop-loss sell orders suggests an intensification of any profitable downtrend thereafter.

Now suppose our investment manager wishes to protect an open position using stop-loss orders. It would not be wise to place the stop-loss orders above a round number, because takeprofit buy orders cluster in that same range and their execution will tend to end any unfavorable downtrend. It would be wise to place a trigger rate just below the round number, given that other traders will already have placed stop-loss sell orders in that region that will tend to reinforce any unfavorable downtrend.

In short, existing patterns in the placement of take-profit and stop-loss orders will be reinforced by the rational placement of further orders. The clustering decisions are thus strategic complements and the clustering patterns can be sustained in a rational equilibrium. 


\section{CONCLUSION}

Research on currency-market microstructure has produced many insights relevant to the profitability of two common trading strategies: carry trades and technical analysis. A plausible theory for positive average carry-trade returns can be constructed on the basis of the robust finding that exchange-rate returns are heavily influenced by order flow. The profitability of carry-trade investing emerges as a self-fulfilling phenomenon when that observation is combined with additional documented features of currency markets: Leverage is procyclical, investors accumulate positions over time, and investors respond to peer success in adopting trading strategies.

This perspective on the carry trade indicates that carry-trade returns will eventually become fragile, in the sense that a small market setback can easily turn into a crash. The fragility appears to reflect the procyclicality of leverage and the reliance of carry-trade investors on positive-feedback trading to protect their positions. The market's reliance on protective stop-loss orders, a specific form of positive-feedback trading, helps explain why currency crashes tend to be concentrated in just a few days.

Positive net returns to carry-trade investing can be a long-run equilibrium phenomenon because the key investing decisions are strategic complements. The more investors open carrytrade positions, the greater the incentive for other traders to open carry-trade positions. The more investors protect carry-trade positions with positive-feedback trading strategies, the greater the incentive for other traders to adopt the same protective strategies.

This perspective on the carry trade helps explain some broad features of exchange rate returns, including the negative skewness associated with returns to investment currencies and the positive skewness associated with funding currencies. It also clarifies some of the subtle causal 
connections behind the emerging evidence on carry trades. This perspective can explain, for example, why interest differentials are positively related to interdealer order flow even though dealers generally do not participate in the carry trade.

The profitability of trend-following technical trading strategies in currency markets could reflect the same microstructurally based processes used to explain carry-trade returns. The technical signals of upcoming trends may have been identifying self-fulfilling trends generated by carry-trade activity. Alternatively, the technical trading signals themselves may have triggered self-fulfilling dynamics.

Currency microstructure research also sheds light on the ability of technical trading signals that predict trend reversals. This success of these signals follows naturally from the very uneven observed distribution of stop-loss and take-profit orders across different exchange-rate levels. The clustering patterns in these orders, like the skewed returns to carry trades, appear to represent self-reinforcing equilibria that result from embedded strategic complementarities.

Beyond the carry trade and technical analysis, the active trading community relies heavily on two other currency trading strategies. One involves deviations from purchasing power parity, the other involves exchange-rate volatility and currency options. Given the contributions of microstructure to explaining returns to carry-trade investing and to technical trading strategies, one can reasonably expect that microstructure will likewise prove valuable in explaining the profitability of these remaining strategies.

\section{DISCLOSURE STATEMENT}

The author is not aware of any affiliations, memberships, funding, or financial holding that might be perceived as affecting the objectivity of this review. 


\section{LITERATURE CITED}

Abreu D, Brunnermeier M. 2003. Bubbles and crashes. Econometrica 71: 173-204

Adrian T, Shin H. 2008. Liquidity and leverage. Fed. Res. Bank N.Y. Staff Rep. 328

Allen, HL, Taylor MP. 1990. Charts, noise, and fundamentals in the foreign exchange market. Econ. J. 29: 49-59.

Amen S. 2010. Identifying where FX market positioning is bucketed with a real-time FX positioning index, Nomura International. Glob. Foreign Exchange Res. Accessed on Oct. 13, 2011. http://www.nomuranow.com/research/globalresearchportal/GetPub.aspx?pid=378903

Bagehot W. 1971. The only game in town. Financ. Anal. J. 27:12-17

Bank for International Settlement. 2010. Triennial Central Bank Survey of Foreign Exchange and Derivatives Market Activity in April 2010. Monetary and Economics Department, Bank for International Settlement

Barber BM, Odean T. 2000. Trading is hazardous to your wealth: the common stock investment performance of individual investors. J. Finance 55:773-806

Bender J, Osler C, Simon D. 2012. Noise traders and illusory correlations in U.S. equities. Rev. Finance. Epub ahead of print; doi: 10.1093/rof/rfr037

Berger D, Chaboud A, Chernenko S, Howorka E, Wright J. 2008. Order flow and exchange rate dynamics in electronic brokerage system data. J. Int. Econ. 75: 93-109

Bernanke B. 2004. The great moderation. Remarks by Governor Ben S. Bernanke at the meetings of the Eastern Economic Association, Washington, DC, February 20, 2004. http://www.federalreserve.gov/boarddocs/speeches/2004/20040220/default.htm, accessed 8/18/2012.

Bernhardt D, Dvoracek V, Hughson E, Werner I. 2005. Why do larger orders receive discounts on the London Stock Exchange? Rev. Financ. Stud. 18:1343-68

Bessembinder H, Chan K.. 1998. Market efficiency and the returns to technical analysis. Finan. Manag. 27:5-17

Biais B, Glosten L, Spatt C. 2005. Market microstructure: A survey of microfoundations, empirical results, and policy implications. J. Financ. Mark. 8:217-64

Bjønnes GH, Rime D. 2005. Dealer behavior and trading systems in foreign exchange markets. J. Financ. Econ. 75:571-605

Bjønnes GH, Rime D, Solheim HOA. 2005. Liquidity provision in the overnight foreign exchange market. J. Int. Money Finance 24:175-96

Bjønnes G, Osler C, Rime D. 2011. Asymmetric Information in the interdealer foreign exchange market. Work. Pap. 2008/25, Norges Bank

Bodnar GM, Hayt GS, Marston RC. 1998. 1998 Wharton survey of financial risk management by US non-financial firms. Financ. Manag. 27:70-91

Brandt M, Kavajecz K. 2004. Price discovery in the U.S. Treasury market: the impact of order flow and liquidity on the yield curve. J. Finance 59:2623-54

Breedon F. 2001. Market liquidity under stress: observations in the FX Market. Work. Pap., Bank Int. Settl. Workshop Mark. Liq., Lehman Brothers. http://www.bis.org/publ/bispap02g.pdf.

Breedon F, Vitale P. 2010. An empirical study of portfolio-balance and information effects of order flow on exchange rates. J. Int. Money Finance 29(3): 504-524

Breedon, F., Rime D, Vitale P. 2012. Carry trades, order flow and the forward bias puzzle. Work .Pap.

Brunnermeier M, Nagel S, Pedersen L. 2008. Carry trades and currency crashes. In: Acemoglu D, Rogo K, Woodford M (Eds.), NBER Macroeconomics Annual 200823 (Cambridge, MA: MIT Press): 313-347

Brunnermeier M, Pedersen L. 2008. Market liquidity and funding liquidity. Rev. Financ. Stud. 22:2201-38

Burnside C, Eichenbaum M, Rebelo S. 2006. Carry trade: the gains from diversification. J. Eur. Econ. Assoc. 6:581- 
Burnside C, Eichenbaum M, Rebelo S. 2009. Understanding the forward premium puzzle: a microstructure approach. Am. Econ. J. Macroecon. 1(2):127-54

Burnside C, Eichenbaum M, Kleshchelski I, Rebelo S. 2010. Do peso problems explain the returns to the carry trade? Rev. Financ. Stud. 24:853-91 [**AU: not cited in text; pls add there or delete here**]

Cai J, Cheung Y-L, Lee RSK, Melvin M. 2001. Once-in-a-generation yen volatility in 1998: fundamentals, intervention, and order flow. J. Int. Money Finance 20:327-47

Cao HH, Evans M, Lyons RK. 2006. Inventory information. J. Bus. 79:325-63

Carpenter A, Wang J. 2003. Sources of private information in FX trading. Work. Pap., Aust. Sch. Bus., Univ. N.S.W.

CFTC-SEC (Commodities Futures Trading Commission-Securities and Exchange Commission). 2010. Findings regarding the market events of May 6, 2010. http://www.sec.gov/news/studies/2010/marketevents-report.pdf

Chaboud, A. Chiquoine B, Hjalmarsson E, Vega C. 2009. Rise of the machines: algorithmic trading in the foreign exchange market. Federal Reserve Board of Governers International Finance Discussion Papers 980

Chang PHK, Osler CL. 1999. Methodical madness: technical analysis and the irrationality of exchange-rate forecasts. Ec. J. 109: 636-661

Cheung Y-W, Chinn MD. 2001. Currency traders and exchange rate dynamics: a survey of the US market. J. Int. Money Finance 20:439-71

Cheung Y-W, Chinn MD, Marsh I. 2004. How do U.K.-based foreign exchange dealers think their market operates? Int. J. Finance Econ. 9:289-306Chordia T, Roll R, Subrahmanyam A. 2002, Order imbalance, liquidity, and market returns, J. Financ. Econ. 65: 111-130

Citi FX Pro. 2010. Methodology and performance. Accessed on Oct. 24, 2001. http://mediaserver.fxstreet.com/Reports/cb7ef736-e010-408d-b29d-ff8d1cd330b7/306073d0-17a8-45f5-995e4df87d78ba9d.pdf

Clarida R, Davis J, Pedersen N. 2009. Currency carry trade regimes: beyond the Fama regression. J. Int. Money Finance 28: 1375-89

Covrig V, Melvin M. 2005. Tokyo insiders and the informational efficiency of the yen/dollar exchange rate. Int. J. Finance Econ. 10:185-93

Danielsson J, Love R. 2006. Feedback trading. Int. J. Finance Econ. 11:35-53 [**AU: update as meant??**]

Della Corte P, Sarno L, Tsiakas I. 2011. Spot and forward volatility in foreign exchange. J. Financ. Econ. 100:496513

Ding L. 2008. Market structure and dealer's quoting behavior in the foreign exchange market. J. Int. Financ. Mark. Inst. Money 18(4):313-25

Dueker M, Neely CJ. 2007. Can Markov switching models predict excess foreign exchange raturns? J. Bank. Finance 31:279-96

Duffie D, Garleanu N, Pedersen LH. 2004. Over-the-counter markets. Econometrica 73:1815-47 [**AU: not cited in text; pls add there or delete here**]

Easley D, O’Hara M. 1987. Price trade size, and information in securities markets. J. Financ. Econ. 19:69-90

Engel C. 1996. The Forward discount anomaly and the risk premium: a survey of recent evidence. J. Empir. Finance 3:123-92

Evans M. 2002. FX trading and exchange rate dynamics, J. Finance. 57: 2405-2448

Evans M. 2010. Order flows and the exchange rate disconnect puzzle. J. Int. Econ. 80:58-71

Evans M, Lyons RK. 2002. Order flow and exchange rate dynamics. J. Polit. Econ. 110:170-80 
Evans M, Lyons RK. 2005. Meese-Rogoff redux: micro-based exchange-rate forecasting. Am. Econ. Rev. 95:405-14

Evans M, Lyons RK. 2007. Exchange-rate fundamentals and order flow. Work. Pap. 13151, NBER

Evans M, Lyons RK. 2008. How is macro news transmitted to exchange rates? J. Financ. Econ. 88:26-50

Fahri E, Frieberger S, Gabaix X, Ranciere R, Verdelhan A. 2009. Crash risk in currency markets. Work. Pap. 15062, NBER

Faust J, Rogers J, Wright J. 2003. Exchange rate forecasting: the errors we've really made. J. Int. Econ. 60(1):35-59

Federal Reserve Bank of New York. 2004. Managing operational risk in foreign exchange. Accessed on Oct. 25, 2011. http://www.newyorkfed.org/fxc/2004/fxc041105b.pdf

Foucault T. 1999. Order flow composition and trading costs in a dynamic limit order market. J. Financ. Mark. 2:99134

Frankel JA, Galli G, Giovannini A, eds. 1996. The Microstructure of Foreign Exchange Markets. Chicago: Univ. Chicago Press

Froot KA, Ramadorai T. 2005. Currency returns, intrinsic value, and institutional-investor flows. J. Finance 60(3):1535-66

Genotte G, Leland H. 1990. Market liquidity, hedging, and crashes. Am. Econ. Rev. 80:999-1021

Glosten L. 1989. Insider trading, liquidity, and the role of the monopolist specialist. J. Bus. 62:211-35

Glosten LR, Milgrom PR. 1985. Bid, ask, and transaction prices in a specialist market with heterogeneously informed traders. J. Financ. Econ. 14:71-100

Glosten L, Harris L. 1988. Estimating the components of the bid/ask spread. J. Financ. Econ 21: 123-42

Goodhart C. 1988. The foreign exchange market: a random walk with a dragging anchor. Economica 55:437-60

Green RC, Hollifield B, Schurhoff N. 2007. Financial intermediation and the costs of trading in an opaque market. Rev. Financ. Stud. 20:275-314

Grossman S, Miller M. 1988. Liquidity and market structure. J. Finance 1988:617-33

Harris L. 1998. Optimal dynamic order submission strategies in some stylized trading problems. Financ. Mark. Inst. Instrum. 7:1-75

Harvey C, Siddique A. 2000. Conditional skewness in asset pricing tests. J. Finance 55:1263-95

Hau H, Killeen W, Moore M. 2002. How has the euro changed the foreign exchange market? Econ. Policy 151-177.

Heimer RZ, Simon D. 2011. Facebook finance: how social interaction propagates active investing. Work. Pap. Brandeis Univ. Int. Bus. Schl.

Hodrick R. 1987. Empirical Evidence on the Efficiency of Forward and Futures Foreign Exchange Markets. New York. Taylor \& Francis

Huang RD, Stoll HR. 1997. The components of the bid-ask spread: a general approach, Rev. Financ. Studies 10: 995-1034

IIROC (Investment Industry Regulatory Organization of Canada). 2010. Review of the market events of May 6, 2010. Accessed on Oct. 14, 2011. http://sdocs.iiroc.ca/English/Documents/2010/C6CB526F-9325-4DED-9F4F98CDCB935FF3_en.pdf

Jurek JW. 2009. Crash-neutral currency trades. Presented at Annu. Meet. Am. Finance Assoc., Atlanta

Kaniel R, Liu H. 2006. So what orders do informed traders use? J. Business 79: 1867-1913

Kaustia M, Knüpfer S. 2011. Peer performance and stock market entry. J. Financ. Econ. 104:321-38

Kavajecz K, Odders-White E. 2004. Technical analysis and liquidity provision. Rev. Financ. Stud. 17:1043-71

Killeen W, Lyons RK, Moore M. 2006. Fixed versus flexible: lessons from EMS order flow. J. Int. Money Finance 25:551-79 
King M, Osler C, Rime D. 2012. Foreign exchange market structure, players, and evolution. In Handbook of Exchange Rates, ed. J James, I Marsh, L Sarno. New York/London: Wiley \& Sons [**AU: see in text queries; otherwise, ref not cited in text**]

Kyle A. 1985. Continuous auctions and insider trading. Econometrica 53:1315-35

Levich R, Thomas L. 1993. The significance of technical trading rule profits in the foreign exchange market: a bootstrap approach. J. Int. Money Finance 12:451-74

Love R, Payne R. 2003. Macroeconomic news, order flows, and exchange rates. Work. Pap., Lond. Sch. Econ.

Lui Y-H, Mole D. 1998. The use of fundamental and technical analysis by foreign exchange dealers: Hong Kong evidence. J. Int. Money Finance 17:535-45

Lustig H, Verdelhan A. 2007. The cross section of foreign currency risk premia and consumption growth risk. Am. Econ. Rev. 97(1):90-117

Lyons RK. 1997. A simultaneous trade model of the foreign exchange hot potato. J. Int. Econ. 42:275-98

Lyons RK. 2001. The Microstructure Approach to Exchange Rates. Cambridge, MA: MIT Press

MacDonald R. 2000. Expectations formation and risk in three financial markets: surveying what the surveys say. $J$. Econ. Surv. 14:69-100

Madhavan AN. 2000. Market microstructure: a survey. J. Financ. Mark. 3:205-58

Madhavan AN, Smidt S. 1993. An analysis of changes in specialist inventories and quotations, J. Finance 48: 15951628

Malkiel B. 1990. A Random Walk Down Wall Street. New York: WW Norton

Mancini L, Ranaldo A, Wrampelmeyer J. 2011. Liquidity in the foreign exchange market: measurement, commonality and risk premiums. Work. Pap. Swiss Nat. Bk.

Meese RA, Rogoff K. 1983. Empirical exchange rate models of the seventies: do they fit out of sample? J. Int. Econ. 14:3-24

Melvin M, Taylor M. 2009. The crisis in the foreign exchange market. Work. Pap. 2707, CESifo

Menkhoff L. 2001. Importance of technical and fundamental analysis in foreign exchange markets. Int. J. Finance Econ. 6:81-93

Menkhoff L, Gehrig T. 2006. Extended evidence on the use of technical analysis in foreign exchange. Int. J. Finance Econ. 11:327-38

Menkhoff L, Sarno L, Schmeling M, Schrimpf A. 2011. Carry trades and global FX volatility. J. Finance 67:681718

Menkhoff L, Taylor MP. 2006. The obstinate passion of foreign exchange professionals: technical analysis. J. Econ. Lit. 45:936-72

Mitchell M, Pedersen LH, Pulvino T. 2007. Slow-moving capital. Am. Econ. Rev. 97:215-20

Moore M, Payne R. 2011. On the sources of private information in FX markets. J. Bank. Finance 35:1250-62

Morris S, Shin HS. 2004. Liquidity black holes. Rev. Finance 8:1-18

Naik NY, Neuberger A, Viswanathan S. 1999. Trade disclosure regulation in markets with negotiated trades. Rev. Financ. Stud. 12:873-900

Niederhoffer V, Osborne MFM. 1966. Market making and reversals on the stock exchange. J. Am. Stat. Assoc. 61:897-916

Nolte I, Nolte S. 2011. How do individual investors trade? Eur. J. Finance. Epub ahead of print; doi: $10.1080 / 1351847 X .2011 .601647$ 
Obstfeld M, Rogoff K. 2003. Foundations of International Macroeconomics. Cambridge, MA: MIT Press

Olson D. 2004. Have trading rule profits in the currency markets declined over time? J. Bank. Finance 28:85-105

Osler CL. 2000. Support for resistance. FRBNY Econ. Policy Rev. 6(2):53-68

Osler CL. 2003. Currency orders and exchange-rate dynamics: an explanation for the predictive success of technical analysis. J. Finance 58:1791-819

Osler CL. 2005. Stop-loss orders and price cascades in currency markets. J. Int. Money Finance 24:219-41

Osler CL, Savaser T. 2011. Extreme returns: the case of currencies. J. Bank. Finance 35:2868-80

Osler CL, Vandrovych V. 2007. Which customers bring information to the in foreign exchange market? Work. Pap., Brandeis Int. Bus. Sch., Brandeis Univ.

Osler CL, Simon D, Sherman R. 2012. Intraday dynamics of foreign exchange spreads. Work. Pap., Brandeis Int. Bus. Sch., Brandeis Univ.

Park CH, Irwin S. 2007. What do we know about the profitability of technical analysis? J. Econ. Surveys 21: 786826

Payne R. 2003. Informed trade in spot foreign exchange markets: an empirical investigation. J. Int. Econ. 61:307-29

Phylaktis, K, Chen L. 2010. Asymmetric information, price discovery, and macroeconomic announcements in FX markets: do top trading banks know more? Int. J. Finance Econ. 15: 228-246

Plantin G, Shin H. 2008. Carry trades and speculative dynamics. Work. Pap., Toulouse Sch. Econ., Univ. Toulouse

Ramadorai T. 2006. Persistence, performance, and prices in foreign exchange markets. Discuss. Pap. 5861, CEPR

Reiss PC, Werner IM. 1995. Transaction costs in dealer markets: evidence from the London Stock Exchange. In The Industrial Organization and Regulation of the Securities Industry, ed. A Lo. Chicago, IL: Univ. Chicago Press

Reitz S, Schmidt MA, Taylor MP. 2009. Financial intermediation and the role of price discrimination in a two-tier market. Deutsche Bundesbank Res. Centre Disc. Pap. Series 1: Econ. Studies 2009-13.

Rime D, Sarno L, Sojli E. 2010. Exchange-rate forecasting, order flow, and macro information. J. Int. Econ. 80:7288

Sager M, Taylor MP. 2006. Under the microscope: the structure of the foreign exchange market. Int. J. Finance \& Econ. 11: 81-95

Savin G, Weller P, Zvingelis J. 2007. The predictive power of head-and-shoulders price patterns in the U.S. stock market. J. Financ. Econom. 5:243-65

Shleifer A. 1986. Do demand curves slope down? J. Finance 41:579-90

Shleifer A, Vishny RW. 1997. The limits of arbitrage. J. Finance 52(1):35-55

Simon DP. 1991. Segmentation in the Treasury bill market: evidence from cash management bills. J. Financ. Quant. Anal. 26:97-108

Simon DP. 1994. Further evidence on segmentation in the Treasury bill market. J. Bank. Finance 18:139-51

Stoll H. 1978. The supply of dealer services in securities markets. J. Finance 33:1133-51

Taylor MP, Allen H. 1992. The use of technical analysis in the foreign exchange market. J. Int. Money Finance $11: 304-14$ 
${ }^{1}$ As in equity markets, when returns are regressed on order flow calculated using the value of trades rather than the number of trades produce consistent results.

${ }^{2}$ The treatment of stop-loss buy- and sell orders is not symmetric in equity markets. Because investors typically have positive holdings of shares, stop-loss sell orders for shares are more common than stop-loss buy orders.

Furthermore, stop-loss sell orders must be treated with special care to ensure that short-sale restrictions are not violated upon their execution.

${ }^{3}$ Since proprietary traders at banks sometimes hold open carry positions, one might wonder if these positions could explain the connection between interdealer order flow and interest differentials. But this would require that the proprietary carry positions are opened with aggressive trades, which may be unlikely. Dealers will view information about carry-trades returns as long-lived, and Kandel \& Liu (2006) show that rational informed investors with longlived information will use limit orders rather than market orders.

${ }^{4}$ Some carry-trade investors protect their positions with options rather than orders, as indicated by the positive relation between risk-reversal prices and returns noted in Amen (2010). This does not eliminate the positivefeedback trading associated with currency crashes, but instead shifts it from investors to option dealers. 
Figure 1: A popular carry trade. Figure 1A shows the exchange rate as yen per dollar. Figure 1B shows short-term interest rates in Japan and New Zealand.
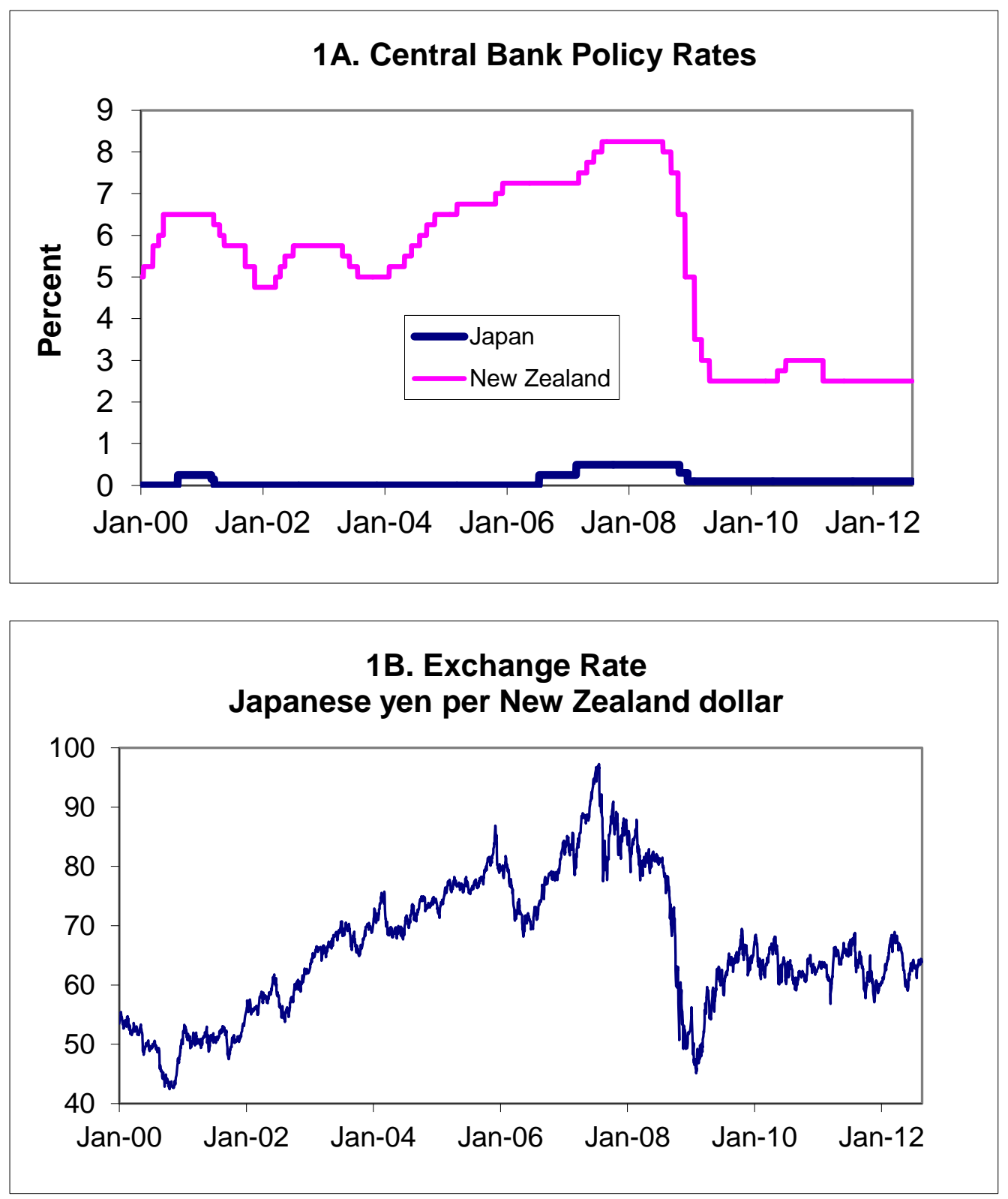